\title{
EDITORIAL
}

\section{Saúde da Mulher Trabalhadora}

A saúde da mulher está diretamente relacionada às condições de vida e trabalho às quais está inserida. Abordar o tema saúde feminina de maneira simplista, que busque somente o tratamento de complicações/disfunções físicas é, no mínimo uma grande imprudência.

Em uma visão global e de equidade, a Organização das Nações Unidas propôs nos Objetivos de Desenvolvimento Sustentável um conjunto de ações para acabar com a pobreza, proteger o planeta e assegurar paz e prosperidade para todos. Dos 17 objetivos construídos, o número cinco diz respeito à igualdade de gênero, empoderamento de mulheres e meninas e direito das mulheres. 0 prazo limite para apresentação de resultados positivos de indicadores de desenvolvimento é 2030. Na realidade brasileira, no entanto, observa-se que esta meta, infelizmente, ainda está longe de ser atingida.

A participação da mulher no mercado de trabalho cresceu de forma exponencial e é caracterizada com acúmulo de responsabilidades (domésticas e laborais) e desvalorização na renumeração. Dentre os inúmeros postos de trabalho destaca-se a de pesquisadora-educadora. Neste posto, a participação da mulher é de extrema relevância, sendo responsável por mais de um terço das publicações científicas. Em países como Brasil e Japão, mais de 70\% dos artigos científicos são assinados por mulheres.

Nesta configuração, o impacto do equilíbrio de gênero na ciência elucidou dúvidas importantes acerca da saúde da mulher em diversos contextos, incluindo o da mulher trabalhadora, o da mãe trabalhadora e o do adoecimento da profissional de saúde.

Novas perguntas começaram a ser respondidas como: O que podemos fazer para promover saúde física e mental à mulher de forma integral e acessível? E, como avaliar e descrever a saúde feminina de forma mais abrangente?

Neste diálogo entre pesquisa, políticas públicas específicas para a mulher e assistencialismo, baseado em evidências e humanização, tem-se a busca real de um estado de saúde que contemple os fatores físico, mental e social.

Este número da Revista Família, Ciclos de Vida e Saúde no Contexto Social, traz a maioria dos artigos assinados por mulheres pesquisadoras-educadoras, com a proposta de informações de qualidade para basear a prática e atuação na saúde integral da mulher.

\section{Boa Leitura!}

\section{Suraya Gomes Novais Shimano}

Fisioterapeuta. Especialista em Reabilitação em Ortopedia e Traumatologia. Mestre em Bioengenharia. Doutora em Ciências da Reabilitação.

Professora do Departamento de Fisioterapia Aplicada, Tutora/vice coordenadora de área do Programa de Residência Multiprofissional em Saúde - Saúde do idoso da Universidade Federal do Triângulo Mineiro. 